\author{
Тихолирова O. K., \\ аспірант кафедри державного управління \\ Київського національного університету імені Тараса Шевченка
}

\title{
ПУБЛІЧНА ІНФОРМАЦІЙНА СИСТЕМА ЯК ТЕХНОЛОГІЧНИЙ ЗАСІБ ОРГАНІЗАЦІЇ ІНФОРМАЦІЙНОЇ ПОЛІТИКИ ДЕРЖАВИ
}

\begin{abstract}
Анотація. У статті здійснено спробу систематизації науково-дослідної інформації щодо суті та специфіки публічної інформаційної системи як способу організації форми інформаційної політики держави під впливом розвитку інформаційно-комунікаційних технологій. Автор обгрунтовує, що публічні інформаційні системи існували завжди, від моменту появи держави як суспільного інституту, але їх характеристики значно змінилися під впливом тотальної діджиталізації. Проаналізовано різні типи даних, які використовуються в межах відповідних систем (оперативні, директивні, процедурні, метадані тощо), способи їх взаємодії та взаємовпливу. Доведено, що сучасні інформаційні системи демократичних держав сприяють залученню громадян через інтерактивність, доступність і прозорість, у результаті чого зміцнюються демократичні принципи і розширюються комунікаційні канали між акторами публічного, приватного та третього секторів. Публічні інформаційні системи відкрили доступ до інформації широкому загалу, чим посприяли більшій активності різних соціальних спільнот. Окрім цього, пряма комунікація між політичними акторами різних суспільних секторів часто заміняється онлайн-спілкуванням, завдяки чому заощаджуються різні ресурси (час, фінанси тощо). Ефективність публічних інформаційних технологій дозволяє говорити про них як про суспільне благо.
\end{abstract}

Попри існування різних інформаційних систем, вони всі можуть бути віднесені до категорії публічних через те, що саме держава визначає межі та правила їх функціонування. До кластера проблемних аспектів віднесено питання співвідношення відкритості даних і конфіденційності, безпеки держави та її громадян перед загрозами терористичних атак.

Акцентуація на системній складовій частині інформаційної політики держави дозволяє виділити іiї два ключові вияви: зміст і форму. Публічні інформаційні системи являють собою спосіб організації інформаційної політики, зміст же останньої безпосередньо пов'язаний із політичними преференціями, ідеалами та цілями, культурними прерогативами кожної окремої країни.

Публічні інформаційні системи можна визначити як такі, що надають послуги громадськості (людям, компаніям, організаціям); надають можливості громадянам, компаніям і організаціям здійснювати демократичний вплив; підтримують уряди всіх рівнів для ефективного та надійного виконання їхніх завдань; утримують, зберігають та надають корисні дані.

Ключові слова: інформаційна політика держави, публічна інформаційна система, інформаційно-комунікаційні технології, канали комунікації, дані, послуги, суспільне благо, громадяни, клієнти, загальнодоступність.

Постановка проблеми. Інформаційна політика держави має два основні вияви: перший стосується змістового наповнення, другий - способу організації, форми. На сучасному етапі розвитку інформаційно-комунікаційних технологій (далі - IКТ) активно просунулося питання технологічної організації інформаційної політики держави, яка сьогодні постає у вигляді системи публічної інформаційної політики. Динаміка розвитку IКТ спричинює посилену увагу теоретиків і практиків до структурування, обробки та надання публічних даних. Однак зміст інформаційної політики держави визначає іiі форму, отже, демонструє готовність держави та ії установ бути відкритими, доступними та підзвітними перед громадянським суспільством.

Аналіз останніх досліджень і пуб̆лікацій. В українському політологічному дискурсі інформаційна політика держави $€$ одним із найбільш актуалізованих предметів, але наукові розвідки переважно стосуються нормативно-правового регулювання інформаційної політики, принципів формування, завдань, особливостей реалізації у вітчизняних реаліях і напрямів удосконалення. Зокрема, можна виділити праці таких дослідників, як I. Березовська [1], О. Литвиненко [2], Г. Почепцов [3], С. Чукут [4] та ін. А ось аналіз публічних інформаційних систем в Україні, по суті, є табуля раса, на відміну від дослідницького ареалу розвинених країн (Д. Венрайт [5], Б. Сандгрен [6], С. Фінберг [7] та ін.). Не достатньою мірою ще досліджені різновиди даних, що зберігаються в публічних інформаційних системах, морально-етичні аспекти проблеми тощо.

Мета статті полягає в дослідженні змісту публічної інформаційної системи як структурованого вияву інформаційної політики держави, сучасної високотехнологічної форми збору, зберігання та поширення публічної інформації.

Виклад основного матеріалу дослідження. Публічна інформаційна система в найбільш загальному вигляді може бути визначена як інформаційна система, доступна для громадського використання. Більш деталізовану дефініцію пропонує Л. Орман і стверджує, що загальнодоступні інформаційні системи можна розглядати як «системи, призначені для використання загальною громадськістю, а не спеціалістами в певній галузі чи організації» [8]. Він виділяє три покоління публічних інформаційних систем:

1) системи пакування інформації, які забезпечують мінімальний обмін;

2) системи пошуку інформації з можливістю використання й обміну даними, але не процесами;

3) системи обробки інформації, які забезпечують максимальний обмін даними та процесами.

Інформаційні системи публічного управління - це концепт та дослідницька область, пов'язана 3 публічними інформаційними системами [9]. Інформаційна система публічного управління зазвичай визначається як інформаційна система, що використовується в державному управлінні, тобто організаціями, 
що належать до державного сектора. Як наслідок такого визначення формується думка про те, що існують приватні інформаційні системи (використовуються організаціями, що належать до приватного сектора). Б. Бозман і С. Бредшнайдер в одній зі статей доводять, що існують важливі відмінності між публічною та приватною інформаційними системами. Але згодом сам Б. Бозман доходить висновку, що всі організації є публічними: «Організація є публічною тією мірою, якою вона діє або є обмеженою політичною владою» [10].

Визначення публічної інформаційної системи як інформаційної системи, доступної для громадського використання (незалежно від того, належить інформаційна система публічному чи приватному сектору), залишає відкритими низку питань, які мають бути, на нашу думку, проаналізовані:

1) що таке «громадське використання»?

2) чи стосуються публічні інформаційні системи лише публічних даних?

3) чи повинні публічні інформаційні системи (та їхні результати) бути безкоштовними загальнодоступними благами?

4) якою мірою публічні інформаційні системи пов'язані з органами державної влади?

Вихідним пунктом у розгляді цих питань буде перелік типів застосувань інформаційної системи:

- інформаційні системи, що надають загальнодоступні дані й інші «корисні дані» громадськості, наприклад, офіційна статистика, карти, каталоги, словники, енциклопедії, каталоги товарів і послуг, події, стандарти, патенти тощо;

- інформаційні системи, що підтримують окремих суб' єктів (осіб, компанії тощо), які потребують / бажають виконати певне завдання щодо державного органу чи установи;

- інформаційні системи підтримки соціальних процесів із залученням як громадян, так і державних органів влади й інших суб'єктів, наприклад, демократичні процеси, процеси щодо шкільного навчання тощо;

- інформаційні системи, що підтримують бізнес-завдання органів державної влади й установ щодо окремих суб'єктів (фізичних чи юридичних осіб), наприклад, завдання поліції, медичні й соціальні послуги тощо;

- засоби масової інформації як «четверта влада» та їхні системи для інформування загальної громадськості, ретельної перевірки влади й обстоювання інтересів громадян;

- інформаційні системи, що підтримують інші загальнодоступні інформаційні системи, тобто інфраструктурні системи, наприклад, оновлення та підтримки баз даних та інформаційних систем, архіви державних інформаційних систем, координація завдань агентства та споживача тощо.

Дослідження публічної інформаційної системи, на наше переконання, має стосуватися аналізу трьох ключових перспектив:

a) прагматичної перспективи (чому i для яких цілей потрібні публічні інформаційні системи?);

б) семантичної перспективи (який зміст публічних інформаційних систем?);

в) синтаксичної перспективи (як будуються публічні інформаційні системи?).

Метою публічної інформаційної системи є надання якоїсь послуги чи підтримка громадського процесу або процесу, що включає широку громадськість або суспільство загалом.
На противагу цьому приватна інформаційна система надає послуги окремим конкретним користувачам, тісно пов' язаним iз певною організацією, виконує деякі конкретні завдання, які часто є внутрішніми для організації, наприклад, внутрішні адміністративні процеси.

Кого можна віднести до «широкої громадськості»? Загалом, це громадяни суспільства. Однак можна розширити цей концепт колективами інших дійових осіб, наприклад, компаніями, особливо невеликими компаніями й організаціями, у яких часто можуть виникати потреби у взаємодіях з органами державної влади, які за своєю суттю схожі на потреби окремих людей. Так, наприклад, це може бути ланцюг завдань щодо отримання якогось рішення, дозволу від владних структур тощо.

Крім того, є певні категорії професіоналів, які підпадають під категорію представників або прихильників «широкої громадськості» та «суспільства загалом», наприклад, журналісти, партійні діячі та дослідники.

Дійові особи, залучені до публічної інформаційної системи, зазвичай належать до трьох таких груп:

1) приватні особи та домогосподарства / сім'ї, які виконують роль громадян, клієнтів, замовників;

2) бізнес-компанії й інші типи організацій, наприклад, некомерційні організації;

3) державні установи на різних рівнях (центральний, регіональний, місцевий).

Громадяни взаємодіють із державними установами та підприємствами, а також з іншими особами; бізнес взаємодіє з державними установами та із замовниками (приватними особами й іншим бізнесом); державні установи взаємодіють із громадянами та підприємствами, а також з іншими державними організаціями.

В окремих ситуаціях взаємодія може включати не лише одну або дві категорії акторів, але й усі три: громадяни, підприємства та державні установи можуть взаємодіяти в межах того самого процесу, наприклад, процесу участі, спрямованого на ухвалення рішення щодо того, де буде розташований бізнес.

Окремий цікавий аспект пов'язаний iз кореляцією публічної інформаційної системи 3 такими актуальними тенденціями, як електронний уряд, електронна демократія й електронна комерція. Передусім варто наголосити на тому, що публічна інформаційна система не є трендовим концептом. Публічні інформаційні системи існували завжди, від початку існування людей як соціальних істот, що намагались досягти спільних цілей. 3 появою та поширенням інформаційно-комунікаційних технологій публічні інформаційні системи можуть скористатися перевагами нових потужних технічний інструментів, які можуть значно підвищити потенціал обробки даних. Поняття «електронний» підкреслює позитивні можливості використання комп'ютеризованих інформаційних систем у всіх сферах сучасного суспільства та необхідність експлуатації їхнього потенціалу. Очевидно, що сфера досліджень публічних інформаційних систем також визнає ці позитивні потенції, але, крім того, визнає той факт, що існує багато інших важливих аспектів і проблем, пов'язаних із комп'ютерною підтримкою публічних інформаційні системи, наприклад, необхідність пропонувати різні модуси зв'язку для різних типів користувачів, включаючи нетехнічні режими і режими, що передбачають інші (некомп'ютерні) технічні засоби. 
Ця сфера також визнає низку інших викликів, які мають бути вирішені в комп'ютеризованому суспільстві: потреби захисту конфіденційності та безпеки, необхідність подолати вразливість суспільства, яка все більше зростає у зв'язку з діджиталізацією інформації та комп'ютеризацією інформаційних систем.

Публічна інформаційна система підтримує завдання (управління справами) та процеси (ухвалення рішень), у яких різні типи акторів беруть участь у різних ролях (громадяни, клієнти, замовники, бізнес, урядові установи). Виконуючи свою підтримуючу роль, публічна інформаційна система та ії користувачі потребуватимуть доступу до даних. Зауважимо, що процеси досліджуваної системи самі будуть генерувати дані. За умови правильної розробки й організації генеровані дані можуть бути повторно використані іншими процесами, тим самим покращуючи ефективність і якість цих процесів.

Дані, які використовуються та виробляються публічною інформаційною системою, можна класифікувати різними шляхами. Зокрема, можна навести таку категоризацію.

Оперативні дані. Необхідні в абсолютному сенсі для обробки та виконання певного завдання. Наприклад, у додатку для електронної комерції покупець повинен вказати ім'я, адресу, замовлену продукцію / послугу тощо, а продавець повинен, зокрема, надати інформацію про доступність і ціну. Оперативні дані можуть бути надані учасником процесу під час виконання завдання або вони можуть бути отримані з уже наявної бази даних.

Директивні дані. На відміну від оперативних даних, не $€$ потрібними в абсолютному сенсі, для належного функціонування підтримуваного процесу директивні, або ж аналітичні, дані, як їх ще називають, мають бути цінними для ефективності процесу та якості результатів. Наприклад, статистичні дані та показники в тій чи іншій формі (окремі таблиці, графіки тощо) часто використовуються у процесах ухвалення рішень, для поліпшення якості рішень.

Процедурні дані. Це описи й інші уявлення про певні правила. Вони можуть випливати із законодавчих процесів, адміністративних процесів чи процесів дизайну. Іноді правила вбудовуються у програмне забезпечення, яке використовує система обробки даних, іноді правила більш чітко відокремлені від процедур, зберігаючись в окремих «базах знань», у яких взаємодіють процедурні алгоритми та процеси.

Метадані. Коротко визначаються як «дані про дані». Зв'язок між даними та метаданими часто може бути досить відвертим, коли, наприклад, метадані описують певні технічні аспекти збережених даних. Зв'язок між даними та метаданими, як і формою метаданих, може бути набагато складнішим, коли метадані спрямовані на опис змісту та значення даних, якості даних щодо релевантності, точності, порівнянності з іншими даними тощо. Метадані повинні допомагати людям у вирішенні таких завдань, як розуміння інших людей у комунікаційних процесах (процеси комунікації можуть бути прямими або непрямими); отримання даних, які вони шукають (дослідницька роль метаданих); інтерпретація даних (пояснювальна роль метаданих); виконання конкретних завдань і операцій (навчальна роль метаданих).

Дані про обробку, або парадані, є фідбеком процесу, про який вони інформують. Наприклад, парадані можуть інформувати про те, була успішно оброблена певна транзакція чи ні, а якщо ні, то яка саме виникла помилка. Парадані можуть використовуватися для сигналізації про проблеми у проєк- туванні або експлуатації публічної інформаційної системи, вони можуть використовуватися як пункт відправлення для поліпшення. Парадані можуть також систематично збиратися, щоб можна було побачити, як різні види акторів ведуть себе, наприклад, на певному вебсайті (хто користувачі, який ступінь іххьої задоволеності тощо). Ураховуючи, що парадані передусім інформують про виконання процесів, вони опосередковано також інформують про якість даних, що виробляються процесами. Отже, парадані можуть також розглядатися як підкатегорія метаданих.

Архівні дані. Їх ще називають записами, відіграють більш важливу роль стосовно майбутніх систем, аніж сучасних. За умови правильного зібрання і організації архівні дані повинні стати відображенням реальних процесів, що постійно зберігаються і підтримуються публічними інформаційними системами. Щоби зробити архівні процеси якомога менше ресурсоспоживаючими, вони повинні бути інтегровані до бізнес-процесів, про які вони інформують, і їх слід автоматично генерувати тими процесами. Такий підхід також може забезпечити повноту та високу якість архівованих записів.

Підсумуємо, що публічна інформаційна система повинна насамперед містити дані, необхідні для виконання завдань відповідної системи. Наприклад, якщо йдеться про допомогу громадянину чи компанії в отриманні якогось урядового дозвола, система повинна містити якомога більше відповідної інформації, щоб уряд міг ухвалити відповідне рішення. Державний орган може вже мати певні дані про заявника, тоді система не повинна просити в заявника ці дані, але вона може запропонувати заявнику можливість перевірити правильність вже існуючих даних. Система також повинна містити інформацію щодо правил, релевантних стосовно конкретного кейсу, наприклад, нормативно-правове забезпечення, політики тощо.

У контексті дослідження даних, що циркулюють у публічній інформаційній системі, не менш важливий аспект, пов'язаний із тим, наскільки ці дані повинні бути загальнодоступними. Країни мають різні закони щодо публікації даних. У такій країні, як Швеція, наприклад, усі дані, які обробляють органи державної влади, $є$ загальнодоступними даними для кожного, якщо тільки не набуває чинності специфічний закон, що робить відповідні дані засекреченими.

Питання публічності, конфіденційності та приватності у зв'язку з використанням комп'ютеризованих інформаційних систем обговорюються вже не одне десятиліття й актуалізують дилему між правом на конфіденційність і потребою знати [11]. I почасти країни, які колись, на початку відповідної дискусії були захисниками конфіденційності, особистої свободи та прав людини, тепер інакше позиціонують себе у зв'язку з терористичними викликами.

Завдяки сучасним інтернет-орієнтованим технікам стало економічно доцільним надання багатьох публічних відомостей системи та її результатів для користувачів (громадяни, компанії тощо) на безкоштовній основі. Це означає, що функціональні можливості та вихідні дані публічної інформації системи часто можна розглядати як суспільні блага або безкоштовні комунальні послуги. Однак іноді може бути виправданим або навіть необхідним стягнення плати 3 користувачів за виконані функції та результати, що забезпечуються системами публічної інформації. Але $€$ низка аргументів на користь безкоштовного користування всіма даними публічних інформаційних систем: 
- після внесення первинних інвестицій у публічну інформаційну систему вартість додавання нового користувача зазвичай дуже низька, наближена до нуля;

- вартість відтворення електронних даних i надання додаткової копії через Інтернет також близька до нуля.

Висновки. Підсумовуючи проведене дослідження, зазначимо, що публічні інформаційні системи відрізняються від інших низкою характеристик, як-от:

1) спільнота користувачів велика, частково невідома та зазвичай неоднорідна;

2) через неоднорідність користувачів кілька каналів між користувачами та виробниками часто мають бути доступні паралельно;

3) оскільки користувачі частково невідомі (і змінюються із часом), для того, щоби розвиватись та постійно змінюватись, необхідно використовувати складні методи, відповідні до поведінки та вподобань користувача;

4) багато публічних інформаційних систем відповідають опису суспільного блага та волі, але пов'язані із проблемами колективного фінансування;

5) публічні інформаційні системи часто містять як публічні дані, так і високочутливі приватні дані (про осіб та / або компаніi);

6) багато публічних інформаційних систем повинні аналізуватися як з погляду користувача / замовника / клієнта, так i з позиції виробника / органу / організації; вимоги не будуть однаковими, а часом навіть будуть суперечливими; такими внутрішніми конфліктами треба керувати, попри складність їх повного усунення.

Отже, можна зробити висновок, що публічні інформаційні системи можна визначити як такі, що надають послуги громадськості (людям, компаніям, організаціям); надають можливості громадянам, компаніям і організаціям здійснювати демократичний вплив; підтримують уряди всіх рівнів для ефективного та надійного виконання їхніх завдань; утримують, зберігають і надають корисні дані для аналізу, планування та дослідження.

\section{Jimepamypa:}

1. Березовська I., Русак Д. Державна інформаційна політика України та основні напрями iï вдосконалення. URL: http:// journals.iir.kiev.ua/index.php/ec_n/article/view/2488/2219 (дата звернення: 17.02.2020).

2. Литвиненко О. Інформаційні технології та Україна у світовому контексті. Людина і політика. 2001. № 1.

3. Почепцов Г., Чукут С. Інформаційна політика : навчальний посібник. Київ : УАДУ, 2002. 96 с.

4. Чукут С. Роль сучасних засобів масової інформації у процесах державотворення : окремі аспекти. Вісник Української академії державного управління. 1999. № 3. С. 158-167.

5. Wainwright D. Consultancy, Learning and Research: The on-going Debate over Rigour Versus Relevance in Information Systems Research. Proceedings of the $10^{\text {th }}$ BIT Annual Conference, e-futures. Manchester Metropolitan University. 2000.

6. Sundgren B., Steneskog G. Information Systems for Concerted Actions. Exploring Patterns in Information Management - Concepts and Perspectives for Understanding Change, Stockholm School of Economic, Economic Research Institute, 2003.
7. Fienberg S. Privacy and Confidentiality in an E-Commerce World: Data Warehousing, Matching, and Disclosure Limitation, Carnegie Mellon University. Pittsburgh, 2005.

8. Orman L. Public Information Systems. Information Society. 1989. Vol. 6. № 1/2.

9. Bozeman B., Bretschneider S. Public Management Information Systems: Theory and Prescription. Public Administration Review. 1986. № 46. P. 475-487.

10. Bozeman B. All Organizations are Public. Jossey-Bass, San Fransisco, 1987.

11. Barabba V. The Right of Privacy and the Need to Know. U.S. Census, 1975.

Tyhomyrova O. Public information system as a technological means of public information politics organizing

Summary. The article attempts to systematize research information on the nature and specificity of the public information system as a way of organizing the form of public information politics under the influence of the development of information and communication technologies. The author argues that public information systems have always existed since the emergence of the state as a public institute, but its characteristics have changed significantly under the influence of total digitalization. The various types of data used within the analyzed systems (operational, policy, procedural, metadata, etc.) and ways of their interaction are researched. It has been proven that modern information systems of democratic states contribute to citizen engagement through interactivity, accessibility and transparency, thereby strengthening democratic principles and widening communication channels between public, private and civil sectors actors. Public information systems have made the information more accessible to the general public, thus contributing to greater involvement of different social communities. In addition, direct communication between political actors from different social sectors is often replaced by online communication, saving different resources (time, finances, etc.). The effectiveness of public information technologies allows us to speak of them as a public good.

Despite the existence of different information systems, they all can be referred to the public category, because the state determines the boundaries and rules of their functioning. The cluster of problematic aspects includes the issue of correlation of data openness and confidentiality, security of the state and its citizens against threats of terrorist attacks.

The accentuation on the system component of the information policy of the state allows to distinguish its two key manifestations: content and form. Public information systems are the way of information politics organizing, while the content is directly related to the political preferences, ideals and goals, cultural prerogatives of each country.

Public information systems can be defined as providing services to the public (people, companies, organizations); empowering citizens, companies and organizations to conduct democratic influence; supporting governments at all levels to carry out their tasks effectively and reliably; retaining, storing and providing useful data.

Key words: public information politics, public information system, information and communication technologies, communication channels, data, services, public good, citizens, clients, public accessibility. 